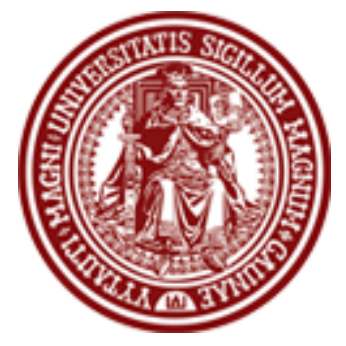

BALTIC JOURNAL OF LAW \& POLITICS

VOLUME 1 (2008)

ISSN 2029-0454

http://www.versita.com/science/law/bjlp

Cit.: Baltic Journal of Law \& Politics 1 (2008): 54-68

10.2478/v10076-008-0004-2

\title{
THE LEGALITY OF OFFSHORE ENTERPRISES
}

\author{
GINTARIJA GUDYNIENE் \\ Assistant Professor; Dr. \\ Vytautas Magnus University Faculty of Law (Lithuania) \\ Contact information \\ Address: S. Daukanto str. 28, LT-44246 Kaunas, Lithuania \\ Phone: 370-37-327873 \\ E-mail address: g.gudyniene@tf.vdu.It
}

Received: December 15, 2008; reviews: 2; accepted: January 19, 2009.

\section{ABSTRACT}

It seems that offshoring is becoming a more and more significant reality today. Offshoring is at the center of a huge public policy debate, which has emerged among business people, politicians, public servants, blue-collar workers and others. Proponents of offshoring see it as bringing prosperity to third-world countries, as well as saving costs and boosting innovation and productivity in corporate high-tax countries. They believe that saving money on cheaper labor benefits consumers due to lower costs and also benefits shareholders because of increased value. Opponents see it as an "assault on good paying jobs" in developed countries. According to them, the negative effect of offshoring is that many individuals lose their jobs, and this consequently hurts the economy of developed countries.

This article analyzes offshoring through the legality of offshore enterprises and raises the question whether the business performed in the form of offshore enterprise and associated with the opportunity to maximize profits on the basis of tax reduction is legitimate, and, if so, what determines the legality of offshore enterprise. The paper also presents the understanding of offshore enterprises in the Lithuanian legal system, and examines whether offshore enterprises are legal within the Lithuanian legal system. 


\section{KEYWORDS}

Offshore enterprise, legality, double taxation, tax planning, tax evasion, tax abuse, tax minimization 


\section{INTRODUCTION}

Employers around the world use different methods and techniques to maximize profits, to regulate taxes and to increase their enterprises' assets as greatly as possible. In the course of pursuing this aim some of these employers pay taxes honestly, to the extent required by the law of the state; others try to find a way to "deviate from this path of honest behaviour". This dilemma similarly arises for Lithuanian businessmen, because every person guided by the common sense thinks about the purposes of taxes, how much of their taxes would be reasonable to pay, and whether there are legal ways to save money. This is the cause of the issues raised in this article - whether the business performed in the form of offshore enterprise is a form of tax evasion, tax abuse or any other crime, and maybe this is a simple use of differences in the national laws of the states to reduce the tax burden?

All over the world the discussion continues as to whether business performed in the form of offshore enterprise and associated with the opportunity to maximize profits on the basis of tax reduction (i.e. whether the regulations of countries or areas where offshore activity takes place provide the possibility to exempt the enterprise from all or at least most of the fees) is legitimate. After all, financial swindlers use offshore enterprises for criminal operations and forgery of documents. Because of these clear legal abuses, the central purpose of this paper is to clarify whether business performed in the form of offshore enterprise is legitimate, and, if so, what determines the legality of offshore enterprise. First this article explains what is meant by the legality of offshore enterprise. Next it identifies and explores two major problems directly connected with the legality of offshore enterprises. The essay concludes with the consequences of these findings.

The first problem arises from the legal questions surrounding many types of offshore enterprises, to which it seems impossible to give a clear and ready answer. The legality of offshore enterprises is primarily determined by the legal regulation of countries or areas where offshore activity takes place with due regard for the pertinent national regulations. In the event of any doubts regarding legality, the responsibility for making a decision lies primarily with the authorities of countries or areas where the enterprise is registered. The second problem, closely related to the first-namely, the legality of offshore enterprises-is the problem of understanding offshore enterprises from within the Lithuanian legal system. 


\section{THE LEGALITY OF OFFSHORE ENTERPRISES, GENERAL DESCRIPTION}

\subsection{THE CONCEPT OF OFFSHORE ENTERPRISE}

Legal literature describes offshore enterprises as having a special organizational and legal status, which helps to reduce taxes. ${ }^{1}$ Typically, such status is associated with the stringent requirements to carry out industrial and commercial services or other activities outside the jurisdiction (the territory) where the offshore enterprise is registered. Only by fulfilling this and other requirements of the regulations of countries or areas where offshore activity takes place is the enterprise exempt from all or at least most of the taxes (there are only a fixed annual fees), i. e. this is when the undertaking becomes an offshore enterprise. The laws generally require that management of the enterprise be carried out within the limits of its registration jurisdiction. In most cases it actually applies to the work of the office. In other words, the offshore enterprise does not have residential status, and is not engaged in any activities within the jurisdiction in which it is registered. ${ }^{2}$ The term "offshore," similar in meaning to "abroad," derives from just this context of being located abroad but necessarily abiding by certain operation regulations of the country where the enterprise is legally registered.

Therefore, if the business is organized in the form of an offshore enterprise, the laws of countries or areas where offshore activity takes place grant the right for this business to be taxed less or with zero tax rates, but only if the business is legal. In order for this business to be legitimate, that is, legally be a business charged with lower or zero tax rates, it must comply with the requirements laid down for such a business in the legislation of those countries or areas. Otherwise, failure to comply with the legal requirements is treated as tax evasion or tax abuse.

Another issue that arises from an analysis of the concept of offshore enterprises is whether it is a legal entity or enterprise, equal to other enterprises. Global legal practice confirms the fact that offshore enterprises are equally involved in practice with other legal and natural persons; ${ }^{3}$ hence in a legal sense offshore enterprise does not differ from other enterprises, because it is an equal legal entity. However, there are set requirements for how offshore enterprises may organize their business out of the limits of jurisdiction in which offshore enterprise is officially registered. Only in this case is offshore enterprise exempt from all or at least most

\footnotetext{
${ }^{1}$ Kęstutis Stungys et al., Ofšorinis verslas (Offshore business) (Vilnius, 2001), p. 12.

2 Exception to this rule is Switzerland, where a certain type of firms can conduct offshore operations in some areas of the cantons, even if they are acting in an office there and have their staff.

${ }^{3}$ Karin B. Sinniger, "The Brave New World of Global Outsourcing," ACCA Docket 23, no. 2 (November 2003): 23.
} 
of the taxes of the parent jurisdiction. In addition, offshore enterprise can carry out business in other countries in full only if there is an international agreement among countries on the avoidance of double taxation with the countries in which offshore enterprise will conduct its business, and the state where it is registered ${ }^{4}$. Otherwise, offshore enterprise may be taxed in the country in which it conducts its business.

Registration of offshore enterprises is possible in jurisdictions whose laws define their special status. In most cases these are small countries, the former or current colonial holdings and other municipal territories with broad rights in a field of taxes. However, the registration of offshore enterprise is available not only in traditional offshore jurisdictions such as Gibraltar, Andorra, the Isle of Man, Lichtenstein, Luxembourg and Cyprus ${ }^{5}$, but also in other countries, for example, the United States of America ${ }^{6}$, Canada, Switzerland, and the Netherlands. The law of most European countries allows offshore activities ${ }^{7}$. Some enterprises which are exempt from paying taxes are allowed to have real offices. For example, in Switzerland certain types of firms are allowed to carry out offshore operations in some cantons, even if they have the acting office and personnel to be employed in these territories. In this case, the obligation to pay the taxes remains; however, tax rates are many times smaller than the basic rate. The methods of offshore business and their implementation are becoming increasingly diverse. Not only corporatetype companies are acting under the current offshore schemes, but also other structures carrying out economic-legal activities. Offshore businesses are increasingly found in the form of a limited liability company (LLC) or some other form of combined companies.

Consequently, the legality of offshore enterprises is inextricably linked to the legal regulation(s) set for offshore enterprises within the particular jurisdiction. So, offshore enterprise can operate legally, if its business is allowed according to the laws of jurisdiction of its registration. However, if the offshore enterprises are engaged in illegal activity (of which the most popular are money-laundering and the implementation of machination), it raises the question of the legality of such undertaking(s), which is examined in each case according to local and international laws.

\footnotetext{
4 Lithuania is a signatory to international treaties on the avoidance of double taxation with other countries.

${ }^{5}$ George Triantafyllides, "Cyprus as an Offshore Centre," International Company and Commercial Law Review 3(12) (1992): 420-425.

6 Steve Lohr, "Opportunity or Threat?," The Hindu (December 23, 2003), the source acquired through the Westlaw database: http://web2.westlaw.com (accessed December 8, 2008) (concluding that offshoring is a natural "pattern of economic change and adjustment in the U.S.").

7 Sergejus Bogdanovičius, Ofšorinès firmos versle (Offshore enterprises in business) (Vilnius, 1999), p. 42.
} 
The legality of offshore enterprises is often questioned by affirming that all legal entities must pay taxes. As has been already mentioned, the unique feature of offshore enterprises is its exemption from all or most of its taxes. So, the question is whether business performed in the form of offshore enterprise is legal, since, according to the legal regulation of offshore activities, offshore enterprises are entitled not to pay taxes or pay very little taxes. However, it is not forbidden for one to organize one's business so that it could be possible to pay taxes in such a state where they are lower or where they do not exist. Thus, the ownership of offshore enterprise is not a crime. If it is correctly managed, its contracts are signed and its payments are made according to the legal regulation(s) of all the countries involved in the transaction(s), then such activity cannot be treated as doubtful or criminal in accordance with the state's legal regulation of offshore enterprises.

\subsection{THE BENEFITS OF OFFSHORE ENTERPRISES}

In order to justify the legality of business performed in the form of offshore enterprises, global legal practice indicates the benefits associated with offshore enterprises - minimum taxable profits or even tax-free profits ${ }^{8}$. This is important both for optimizing the activity of the legal entity and for implementing the goals of an individual or group. Supporters of offshore business argue that any restriction of business performed in the form of offshore firms, or any attempt to determine such business to be illegal leads to inefficiency"; besides, "when jobs can be done more efficiently offshore it pays to let them go." ${ }^{10}$ Studies show that companies which offshore work to lower-waged countries reduce costs by 40 to $60 \% .^{11}$

The foundation of tax-free business is associated with many other advantages of such enterprises beyond just the reduction of income tax. Other possible advantages include: the simplicity of establishing the activities of offshore enterprises (with the exception of regulated businesses, such as banking activities); quick registration as taxpayers; the limited scope of the information about the offshore enterprise required by the institutions of offshore areas states in separate

\footnotetext{
8 David M. Hudanish, Disaster Recovery and Business Continuity in an Evolving Regulatory Framework, 767 PLI/Pat 633, 644 (2003), the source acquired through the Westlaw database: http://web2.westlaw.com (accessed September 28, 2008) (concluding that offshoring is attractive to companies because of the cost saving but it is not without risks).

9 "Protection Won't Work," Straits Times (Singapore) (2003), the source acquired through the Westlaw database: http://web2.westlaw.com (accessed March 12, 2008) (concluding that "offshoring allows American companies to create more economic value through lower costs, new revenue sources, repatriated earnings and redeployed labour.").

10 "Creating Work," Chicago Trib. no. 22 (2003), the source acquired through the Westlaw database: http://web2. westlaw.com (accessed March 19, 2008).

${ }^{11}$ Manjeet Kripalani, Pete Engardio, and Steve Hamm, "The Rise of India," Business Week (December 8, 2003): 66, the source acquired through the Westlaw database: http://web2.westlaw.com (accessed September 8, 2008).
} 
jurisdictions; the securing of assets transferred to the offshore company from the potential property liability; the protection of the confidentiality of the main person's (persons') organizing the business; protection against inflation; the reduction of costs attached to the management of enterprise, such as support and subsidies from local governments; an effective and inexpensive banking system; absence of currency exchange control; the availability of banking services and international management at the global level; easy access to North American and European markets; absence of costly bureaucracy; etc. ${ }^{12}$

The confidentiality offered to an offshore enterprise's actual owner is guaranteed by the aid of a so-called institute of nominal owners and directors. Recorded (official) documents do not contain the names of the real owners, but only the names of the nominal owners. There are secretarial companies which specialize in registering offshore companies, and which provide the services of nominal owners and directors. Sometimes the director of the offshore enterprise is the real owner, but usually a nominal person is appointed as a director. This means that the nominal director only formally takes the post. In fact, he is obliged to carry out only those actions that are assigned to him by the contract. In this case the company is actually controlled by the real owner or his representative who has the power (general or only for certain actions) to undertake legal action on behalf of the enterprise ${ }^{13}$.

As seen from the above analysis, business performed in the form of offshore enterprise has quite a lot of advantages, such as: complete financial privacy; the reduction of income tax; the avoidance of inheritance tax; the restriction of legal liability; the lack of currency exchange control; the confidentiality and almost inaccessibility of data on the owners and directors; the absence of international tax rates; the absence of restrictions on volume of imports and exports. But the question remains: are the advantages of offshore enterprises indeed legal? Yes, they are legal in the sense that the benefits of offshore enterprises are indicated in the legal regulation(s) of the state where the offshore enterprise is registered. However, is the special status granted to offshore enterprises based on advantages a legal way to do business?

\subsection{PROBLEMS AND DISADVANTAGES OF OFFSHORE ENTERPRISES}

Despite the fact that business performed in the form of offshore enterprise is widespread (particularly because of the tax optimization and the confidentiality of

\footnotetext{
12 John Harney, "Offshore Outsourcing - The Ongoing Political Debate," Outsourcing Center (November, 2003), http://www.outsourcing-offshore.com/debate.html (accessed September 12, 2008).

${ }^{13}$ Ibid.
} 
the main persons organizing such a business), offshore enterprises have some disadvantages. In most cases offshore enterprises are not included in the crossborder agreements on avoidance of double taxation. The tax services often pay more attention and very carefully examine all the contracts concluded by enterprises established in preferential tax zones (in targeted areas). In some countries, including Lithuania and its neighbouring countries of Belarus, Russia, and Ukraine, there are anti-offshore laws. In other countries, for example Latvia, Estonia, and Hungary, a much more liberal order is set. Offshore enterprises often experience difficulties in opening bank accounts. In such a case, it is possible to use the help of companies which specialize in the services of offshore enterprises' registration and management ${ }^{14}$.

Of course, there are ways to improve the image of offshore enterprises. It may be registered in a traditional offshore jurisdiction (such as Gibraltar or Jersey), while its office may be set up in London and bank account may be opened here (i.e. in London). From the outside the company appears to be British, but actually it is registered in a traditional offshore jurisdiction.

All over the world there are international crimes - trafficking in weapons, explosives, drugs, people smuggling, money laundering. All the nations of the world connected to the corresponding international conventions and agreements fight against such matters of international crime. Meanwhile, however, it is merely optional to regulate whether a business can avoid paying taxes in another country. Such control and regulation is often considered simply the other states' affairs. However, within the analysis of offshore enterprises, it is necessary to note that they are registered within a certain jurisdiction and must abide by its laws. However, if an enterprise is exempt from paying taxes or has non-residential status, the local government of its registration does not usually care about that enterprise's activities abroad, and whether that business pays taxes in other countries, because, as it was already stated, it is considered the local affairs of other states ${ }^{15}$.

The negative feature of offshore enterprise is the fact that an increase in the number of offshore enterprises increases unemployment, which occurs as a consequence of the businesses having moved to offshore jurisdictions. United States Senator from New Jersey Shirley Turner notes that the states not only lose revenue to offshoring, but when people are unemployed the states have to pay unemployment benefits ${ }^{16}$. A study found that in the last twenty years, only $36 \%$ of

\footnotetext{
${ }^{14}$ Sergejus Bogdanovičius, supra note 7, p. 36.

15 John Harney, supra note 12.

${ }^{16}$ Ibid.
} 
Americans who were displaced by offshoring found jobs at the same or higher pay, while the incomes of a quarter of those people dropped by $30 \%$ or more ${ }^{17}$.

Another negative feature of business performed in the form of offshore firms is related with the prosperity of offshore business. Two-thirds of private money in one way or another "visits" these countries. Such a situation naturally troubles developed countries, most of which are members of the Organization for Economic Cooperation and Development (OECD). From the standpoint of OECD, the tax system applied in offshore contexts is harmful, because it affects international competition. Three international agencies - the Organization for Economic Cooperation and Development (OECD), the Financial Action Task Force on Money Laundering (FATF) and the Financial Stability Forum (FSF) - carried out a full investigation of around fifty of the world's offshore financial centers (OFC) and issued their "blacklists". The OECD in particular works to reduce "unfair tax competition"18. It issued the officially recognized OFC's "black list"19.

Reviewing the disadvantages of business organized in the form of offshore enterprises, again the questions returns, whether such businesses are legitimate? Under the legal regulation of the countries or areas where offshore activity takes place, the offshore business is legal if the enterprise does not participate in the criminal activities. However, the question persists: are the negatives of offshore enterprises and their growth enough of a basis to claim offshore business as illegal within an international framework and perspective? Such a claim seems both reasonable and possible, in particular since, as already mentioned, the Organization for Economic Cooperation and Development (OECD) is actively denouncing the damage caused by offshore enterprise. In addition, most developed countries, most of whom are the members of OECD, have adopted anti-offshore laws in response to harm done to international competition due to the tax privileges applied to offshore enterprises.

\footnotetext{
17 Manjeet Kripalani, supra note 11: 68.

18 See generally Richard A. Johnson, "Why Harmful Tax Practices Will Continue After Developing Nations Pay: A Critique of the OECD's Initiatives Against Harmful Tax Competition," Boston College Third World Law Journal Vol. 26, No. 2 (Spring, 2006), http://www.bc.edu/schools/law/lawreviews/metaelements/journals/bctwj/26_2/twlj_26_2_web.pdf (accessed December 2, 2008). See also generally William Brittain-Catlin, Offshore: The Dark Side of the Global Economy (New York: Farrar, Straus, and Giroux, 2005). Abstract: Offshore tax havens have recently become the target of international criticism and reform efforts due to their role in eroding foreign tax bases through competitive tax practices. William Brittain-Catlin's book, Offshore: The Dark Side of the Global Economy, discusses how offshore tax laws have been exploited and explains measures taken by international groups, such as the Organisation for Economic Co-operation and Development (OECD), to counteract harmful tax competition. This Book Review critiques the efforts of the OECD to mitigate offshore tax havens' contribution to harmful tax competition by expanding on two of Brittain-Catlin's conclusions. In doing so, the Book Review will demonstrate that the OECD's actions have not only caused severe economic harm to numerous developing nation economies, but they have failed to elicit sufficient support to successfully curb harmful tax competition.

19 John Harney, supra note 12.
} 


\section{LEGALITY OF OFFSHORE ENTERPRISES AND LITHUANIAN LEGAL SYSTEM}

This part of paper focuses on the interpretation of the offshore enterprises and their legality set forth in Lithuanian legislation. Thus, are offshore enterprises legal in the Lithuanian legal system? This question can be answered on the basis of the private law principle: everything is permitted that is not prohibited by law. Legislation prohibiting the registration or use of offshore enterprise does not exist in Lithuania ${ }^{20}$. Such a prohibition is unthinkable under current law, because the legal status of offshore enterprises, otherwise known as enterprises of preferential taxation, does not differ in any essential way from other enterprises. They are full and equal legal entities of commercial and economic relations and may conclude transactions just as any other legal entity. However, unlike other enterprises, offshore enterprises are registered in countries or areas where taxes on profit (and other taxes) are much lower than in other countries, or do not exist at all. Nevertheless, the tax-planning structure may include more than just offshore enterprises.

Currently it may be considered illegal to register an offshore enterprise, or to engage in other activities related to offshore enterprise, if it is in violation of public law requirements. For example, in global practice there have been cases where the authorities determine bans; for example, a ban against setting up offshore enterprises or their accounts in foreign banks without the authorities' express permission. In this case, the setting up of offshore enterprise or the opening of its account in foreign bank without prior permission from the relevant authorities is illegal.

\footnotetext{
${ }^{20}$ It should be noted that the legal system of Lithuania includes legal acts in one way or another related to offshore business: Law on Profit Tax of the Republic of Lithuania, Official Gazette (2001, no. 1103992); Law on Personal Income Tax of the Republic of Lithuania, Official Gazette (2000, no. 73-3085); On the Recognition Withdrawn the Ruling No. 888 of August 4, 1997 of the Government of the Republic of Lithuania "For Types of Received Taxable Income and Tax Payment Procedures Related to the Foreign Enterprises, Registered in the Preferential Tax Rate of Countries or Areas (Areas where Taxes are Lower than in the Republic of Lithuania), Legal Persons of the Republic of Lithuania, Having no Legal Personality or Permanent Establishments of Foreign Enterprises in the Republic of Lithuania (except these Cases where Payments are Paid to Foreign Enterprises from their Permanent Establishments)," Official Gazette (2002, no. 17-684); On the Approval of the Procedure for Determining Deductions Related to Income Earned Through Permanent Establishments and the Procedure for Determining the First and Last Taw Periods of a Permanent Establishment, Official Gazette (2002, no. 26-931); On the Recognition Withdrawn the Order No. 115 of April 26, 2001 of the Minister of Finance of the Republic of Lithuania "On the Approval of the List of Countries or Areas (Areas where Taxes are Lower than in the Republic of Lithuania)," Official Gazette (2002, no. 5-193); On the Registration of Permanent Establishments of Foreign Enterprises in the Register of Tax Payers, Informative Reports (2001, no. 41).
} 
The legality of offshore enterprise is also determined by the specific targets of its use. For example, in analyzing one of the offshore enterprise's purposes - tax planning - the first step should be to define the following three related concepts: tax evasion, tax abuse (trying to achieve tax benefits by abusing the law) and tax minimization. Without question the interrelation(s) of these definitions is fairly complex.

Tax evasion is usually considered an intentional and clearly unlawful attempt to avoid taxes: all or in part. This behaviour is related to the violation of legal norms, which typically brings administrative or even criminal liability on its perpetrators. Due to the above indicated features tax evasion can only be relatively attributed to tax planning. It was also noted that tax evasion is considered intentional, willful violation of tax legislation, rather than, for example, behaviour based on different interpretation of tax laws.

Meanwhile, tax abuse (trying to achieve tax benefit by abusing the law) does not formally violate the legal provisions. It is therefore particularly difficult to dissociate tax abuse from tax minimization. As defined under the Law of Tax Administration of the Republic of Lithuania,

The tax abuse - the taxpayer's transaction, the economic operation or any of their group, whose aim is to obtain tax benefits, it means, directly or indirectly to remove the deadlines of tax payment, to reduce the amount of tax due, or to avoid the paying of taxes completely, or to increase the reimbursable tax overpayment (the difference), or to reduce the repayment terms of tax overpayment (the difference) perverting or hiding the circumstances with which are linked taxation procedures of the tax law. It is not considered to be tax abuse the taxpayer's transaction, economic operation or any of their group, whose the main purpose is reasonably regarded as meeting the business needs, and a tax benefit, which appears or may appear as an additional result of such activity. ${ }^{21}$

Under that law, the tax authorities, in determining the tax base and calculating the due amount of tax, do not take into consideration whether the taxpayer failed to comply with the transaction, with the business operation or any of their group whose aim is to get the tax benefit. Instead the tax authorities restore distorted or hidden circumstances with which the taxation regime is connected under the tax law.

In order to declare the transaction void under the provisions of the Civil Code of the Republic of Lithuania ${ }^{22}$, as evidenced by the case law, the tax authority itself cannot declare the transaction void: "According to the Article 1.78 of Civil Code of

\footnotetext{
${ }^{21}$ Law on Tax Administration of the Republic of Lithuania, Official Gazette (2004, no. 63-2243), art. 71.
}

22 Civil Code of the Republic of Lithuania. Official Gazette (2000, no. 74-2262), art. 1.78. 
Lithuanian Republic the transaction is recognized to be void out of Court's order when it is contrary to the imperative rules of law, it means, when the foundations of invalidity of the transaction, set by law, are obvious and there is no need for additional evidences to establish these foundations." ${ }^{23}$

The tax administrator not only cannot recognize the transaction void, but also cannot apply the legal consequences of void transaction: "The tax administrator, as the person concerned, according to the legal sense of Article 1.78/5 of Civil Code of Lithuanian Republic, has the possibility to provide the claim for an ordinary court claiming to apply the legal consequences of the null and void transaction and requiring to declare the transaction invalid." ${ }^{24}$

Unlike the matter discussed above, another form of tax planning, tax minimization (whether direct or indirect), does not violate legal norms. It is closely associated with the values set forth in the European Union law - freedom of establishment and freedom of capital movement. Therefore, in order to reduce the taxes legally, the establishment of offshore enterprise in some of low-tax countries or areas is the perfect opportunity to do it. But it should be stressed, that it should not lead to such activities, when at the end of the year the simple way is choseni.e. to buy the offered written statements of offshore enterprises - "portfolios", merely write one's own personal data in them, thus, become the owner or authorized person of enterprise, and conduct fictitious operations.

Consequently, it can be argued that giving a specific and final answer as to whether the use of offshore enterprise for tax planning purposes is lawful or unlawful, is often impossible. However, this issue does not arise in cases where offshore enterprises are used for activities related to money laundering, drug trafficking and terrorism.

In conclusion, business performed in the form of offshore enterprises may be legitimate if it is not the basis for fictitious transactions or international crimes (such as money laundering, drug trafficking or terrorism), and if the registration of offshore enterprises or other activities related to the offshore enterprises do not violate the requirements of public law.

\footnotetext{
${ }^{23}$ Order of Supreme Administrative Court of the Republic of Lithuania (2003, no. A A $^{-490 / 2003) .}$

${ }^{24}$ Order of Plenary Session of Supreme Administrative Court of the Republic of Lithuania (2003, no. A ${ }^{11}$ $648 / 2003)$.
} 


\section{CONCLUSIONS}

This article analyzes the contemporary understanding of offshore enterprises and if a business performed in the form of offshore enterprise can be legal, and whether there are the bases to claim the legality of offshore enterprises.

The analysis reveals that offshore enterprise is legal on the conditions that the activity(s) of the enterprise is not connected with fictitious operations or with international crimes (such as money laundering, terrorism, drugs and so on), and if the registration of the enterprise or any other activity connected with the offshore enterprise do not violate requirements of public law. The legality of offshore enterprises is connected with the requirements set up for offshore enterprises in a certain country or area where offshore activity takes place. If offshore enterprise follows these requirements, then the activity of the offshore enterprise is legal; if not, then the question of the legality of the enterprise appears. This question must be answered according to national and international laws. Another point revealed during the analysis is that an offshore enterprise is exempt totally or partially from paying taxes in a country or area of its registration, if the enterprise follows the requirements set up in legal regulation of a certain country or area where offshore activity takes place. One of the main requirements is that the activity of offshore enterprise has to be performed offshore, which means, not in a jurisdiction of its registration.

This paper also analyzes if offshore enterprises are legal entities in the Lithuanian legal system and what the possibilities for offshore enterprises to act as equal legal entities in Lithuanian legal system are. The analysis reveals that there is no Lithuanian legal act that prohibits the registration or use of offshore enterprise; consequently, according to the principle of private law-everything is permitted, which is not prohibited by law-offshore enterprise can be legal within the Lithuanian legal system. Moreover, the legality of offshore enterprises can also be determined by the aims of its use; for example, in tax planning, which is different from tax evasion or tax abuse. Thus, it has been concluded that specific and final answer as to whether the use of offshore enterprise for tax planning purposes is lawful or unlawful, is often impossible. However, this issue does not arise in cases where offshore enterprises are registered or used in violation of the requirements of public law, for fictitious operations or activities related to international crimes, all of them making offshore enterprise illegal. 


\section{BIBLIOGRAPHY}

1. Bogdanovičius, Sergejus. Ofšorinès firmos versle (Offshore enterprises in business). Vilnius, 1999.

2. Brittain-Catlin, William. Offshore: The Dark Side of the Global Economy. New York: Farrar, Straus, and Giroux, 2005.

3. "Creating Work." Chicago Trib. no. 22 (2003) // the source acquired through the Westlaw database: http://web2.westlaw.com/ (accessed October 19, 2008).

4. Harney, John. "Offshore Outsourcing - The Ongoing Political Debate." Outsourcing Center (November 2003) // http://www.outsourcingoffshore.com/debate.html (accessed September 12, 2008).

5. Hudanish, David M. Disaster Recovery and Business Continuity in an Evolving Regulatory Framework. 767 PLI/PAT 633, 644 (2003) // the source acquired through the Westlaw database: http://web2.westlaw.com/ (accessed September 28, 2008).

6. Johnson, Richard A. "Why Harmful Tax Practices Will Continue After Developing Nations Pay: A Critique of the OECD's Initiatives Against Harmful Tax Competition." Boston College Third World Law Journal Vol. 26, No. 2 (Spring 2006): 351-375 // http://www.bc.edu/schools/law/lawreviews/metaelements/journals/bctwj/26_2/twlj_26_2_web.pdf (accessed December 2, 2008).

7. Kripalani, Manjeet, Pete Engardio, and Steve Hamm. "The Rise of India." Business Week (December 8, 2003) // the source acquired through the Westlaw database: http://web2.westlaw.com/ (accessed September 8, 2008).

8. Lohr, Steve. "Opportunity or Threat?" The Hindu (December 23, 2003) // the source acquired through the Westlaw database: http://web2.westlaw.com/ (accessed December 8, 2008).

9. "Protection Will not Work." The Straits Times (Singapore) (2003) // the source acquired through the Westlaw database: http://web2.westlaw.com/ (accessed October 12, 2008).

10. Sinniger, Karin B. "The Brave New World of Global Outsourcing." ACCA Docket 23, no. 2 (2003): 14-28.

11. Stungys, Kęstutis, Kazys Galdikas, Ignotas Venslovas, and Algirdas Sakalauskas. Ofšorinis verslas (Offshore business). Vilnius, 2001.

12. Triantafyllides, George. "Cyprus as an Offshore Centre." International Company and Commercial Law Review 3(12) (1992): 420-425. 


\section{LEGAL REFERENCES}

1. Civil Code of the Republic of Lithuania. Official Gazette, 2000, no. 74-2262.

2. Law on Personal Income Tax of the Republic of Lithuania. Official Gazette, 2000, no. 73-3085.

3. Law on Profit Tax of the Republic of Lithuania. Official Gazette, 2001, no. 1103992.

4. Law on Tax Administration of the Republic of Lithuania. Official Gazette, 2004, no. 63-2243.

5. On the Approval of the Procedure for Determining Deductions Related to Income Earned Through Permanent Establishments and the Procedure for Determining the First and Last Taw Periods of a Permanent Establishment. Official Gazette, 2002, no. 26-931.

6. On the Recognition Withdrawn the Order No. 115 of April 26, 2001 of the Minister of Finance of the Republic of Lithuania "On the Approval of the List of Countries or Areas (Areas where Taxes are Lower than in the Republic of Lithuania)." Official Gazette, 2002, no. 5-193.

7. On the Recognition Withdrawn the Ruling No. 888 of August 4, 1997 of the Government of the Republic of Lithuania "For Types of Received Taxable Income and Tax Payment Procedures Related to the Foreign Enterprises, Registered in the Preferential Tax Rate of Countries or Areas (Areas where Taxes are Lower than in the Republic of Lithuania), Legal Persons of the Republic of Lithuania, Having no Legal Personality or Permanent Establishments of Foreign Enterprises in the Republic of Lithuania (except these Cases where Payments are Paid to Foreign Enterprises from their Permanent Establishments." Official Gazette, 2002, no. 17-684.

8. On the Registration of Permanent Establishments of Foreign Enterprises in the Register of Tax Payers. Informative Reports, 2001, no. 41.

9. Order of the Plenary Session of the Supreme Administrative Court of Lithuania. The Supreme Administrative Court of Lithuania, 2003, no. $A^{11}$ 648/2003.

10. Order of the Supreme Administrative Court of Lithuania. The Supreme Administrative Court of Lithuania, 2003, no. A A $^{8} 490 / 2003$. 